Terakreditasi: SK No.: 60/E/KPT/2017

Website : http://ejournal.undip.ac.id/index.php/reaktor/

Reaktor, Vol. 17 No. 3, September Tahun 2017, Hal. 132-138

\title{
Pemetaan Pengaruh Proses Pengolahan pada Kualitas Biji Kakao Menggunakan Metode Metabolik Profiling dengan GC/MS
}

\author{
Made Tri Ari Penia Kresnowati ${ }^{*}$, Hana Nur Fitriana, dan Ronny Purwadi \\ Laboratorium Mikrobiologi dan Teknologi Bioproses \\ Kelompok Keahlian Perancangan dan Pengembangan Produk Teknik Kimia \\ Fakultas Teknologi Industri, Institut Teknologi Bandung \\ Gedung Labtek X, Jl. Ganesha 10, Bandung 40132 \\ Telp./Fax. (022)2500989 / (022)2501438 \\ *)Penulis korespondensi: kresnowati@che.itb.ac.id
}

\begin{abstract}
MAPPING THE EFFECTS OF COCOA POST HARVEST PROCESSING ON COCOA BEAN QUALITY BY METABOLIC PROFILING METHOD USING GC/MS. The quality of cocoa is strongly effected by the implemented post harvest processes. The fermented cocoa beans is presumed to have higher quality than the unfermented ones, whereas roasting strongly affects the organoleptic quality of the cocoa products. However, what exactly differentiates those cocoa beans are not known yet. This research was foccused on the mapping of post harvest processing method on the quality of cocoa beans, using metabolic profiling method. Different types of cocoa bean samples, that were fermented, roasted, fermented and roasted, as well as unfermented and unroasted (as control) were analysed by GC-MS. The obtained metabolic profiles were further mapped using Principal Component Analysis (PCA). The results showed that there were significant different on samples processed through different processing methods. The fermentation and roasting of cocoa beans direct the process such that more homogenous metabolic composition were obtained.
\end{abstract}

Kata kunci: cocoa beans; fermentation; metabolomic; PCA; processing; roasting

\begin{abstract}
Proses pengolahan biji kakao sangat menentukan kualitas kakao yang dihasilkan. Biji kakao terfermentasi diyakini memiliki kualitas yang lebih tinggi dibandingkan biji kakao tanpa fermentasi. Proses penyangraian juga diyakini sangat menentukan kualitas organoleptik produk olahan kakao. Akan tetapi, para pelaku bisnis kakao masih belum mengetahui secara pasti apa yang membedakan hal tersebut. Penelitian ini berfokus pada pemetaan pengaruh proses pengolahan pada kualitas biji kakao, menggunakan metode metabolik profiling. Sampel biji kakao dengan berbagai proses pengolahan: difermentasi, disangrai, difermentasi dan disangrai, serta kontrol (tidak difermentasi dan tidak disangrai) dianalisa dengan GC/MS untuk memetakan komposisi metabolitnya. Spektrum metabolit yang diperoleh kemudian dipetakan menggunakan metode Principal Component Analysis (PCA). Hasil yang diperoleh menunjukkan terdapat perbedaan yang signifikan antara sampel dengan berbagai proses pengolahan tersebut, pengolahan biji kakao yang terdiri dari fermentasi dan penyangraian mengakibatkan komposisi biji kakao yang lebih seragam.
\end{abstract}

Keywords: biji kakao; fermentasi; metabolomik; PCA; pemrosesan; penyangraian 
How to Cite This Article: Kresnowati, M.T.A.P., Fitriana, H.N., dan Purwadi, R., (2017), Pemetaan Pengaruh Proses Pengolahan pada Kualitas Biji Kakao Menggunakan Metode Metabolik Profiling dengan GC/MS, Reaktor, 17(3), 132-138, http://dx.doi.org/10.14710/reaktor.17.3.132-138.

\section{PENDAHULUAN}

Kakao merupakan bahan dasar pembuatan cokelat yang merupakan makanan yang sangat digemari di seluruh dunia. Tanaman kakao termasuk tumbuhan tahunan (perennial) yang dihasilkan oleh banyak negara tropis. Pantai Gading menduduki peringkat pertama dengan menghasilkan 41\% biji kakao dunia, disusul oleh Ghana dan Indonesia yang masing-masing menyumbang sebesar 18 dan $14 \%$ biji kakao dunia. Walaupun menghasilkan biji kakao dalam jumlah besar, biji kakao Indonesia di pasaran internasional dihargai rendah. Hal ini antara lain disebabkan oleh didominasi oleh biji-biji tanpa fermentasi, kadar kotoran tinggi, terkontaminasi serangga, jamur, atau mikotoksin, serta cita rasa yang lemah.

Selain bergantung pada spesies tanaman dan kondisi tanamnya, kualitas biji kakao yang dihasilkan juga sangat bergantung pada pengolahan pasca panennya. Salah satu proses kunci dalam pengolahan pasca panen biji kakao adalah fermentasi biji kakao. Proses fermentasi meluruhkan pulp yang menyelimuti biji kakao dan mengkonversi senyawa-senyawa gula yang terdapat di dalamnya menjadi berbagai produk metabolit seperti etanol, asam laktat dan asam asetat, juga panas metabolik yang akan menghentikan proses germinasi biji kakao. Selanjutnya dalam proses ini dibentuk senyawa-senyawa prekursor aroma dan rasa yang akan sangat menentukan cita rasa biji kakao (Schwan, 1998; Schwan dan Wheals, 2004; Kresnowati dan Febriami, 2016). Oleh karena itu biji kakao hasil fermentasi memiliki harga yang tinggi di pasaran.

Parameter kualitas biji kakao yang diterapkan di Indonesia saat ini umumnya meliputi parameter fisik, mengandalkan uji visual terhadap biji kakao. Parameter kualitas biji kakao yang diterapkan Standard Nasional Indonesia (SNI) meliputi ukuran biji, kadar air, keutuhan biji, keberadaan jamur, serangga, kecambah, atau benda asing, serta terfermentasi atau tidak (SNI 01-2323-1991). Adapun cita rasa biji kakao umumnya diuji secara organoleptik oleh tester yang berpengalaman.

Belakangan ini berkembang teknik metabolomik untuk memetakan profil senyawasenyawa metabolit pada suatu sistem biologis. Metabolomik merupakan suatu pendekatan analitik yang non selektif, berlaku universal, komprehensif untuk mengidentifikasi dan mengkuantifikasi senyawa-senyawa metabolit pada suatu sistem biologis (Wolfender dkk., 2015). Pendekatan ini sangat potensial untuk digunakan dalam analisa ratusan bahkan ribuan senyawa metabolit yang terkandung dalam sistem biologis dan dengan demikian dapat diaplikasikan untuk untuk menjelaskan variasi dalam fenotif yang dipengaruhi oleh genotif, faktor lingkungan dan tekanan fisik
(Halket dkk., 2005; Wolfender dkk., 2015). Pengukuran berbagai senyawa metabolit tersebut dapat dilakukan di antaranya menggunakan kombinasi teknik kromatografi, baik gas maupun cair, dengan teknik spektroskopi massa (LC-MS atau GC-MS) (Kopka, 2006). Perbandingan profil senyawa-senyawa metabolit dapat diaplikasikan untuk menentukan persamaan dan perbedaan antara dua sampel atau lebih, dan disebut sebagai teknik metabolik profiling (Fiehn dkk., 2000). Metode yang awalnya dikembangkan untuk mengkarakterisasi berbagai jenis minuman anggur atau wine (Skogerson dkk., 2009) kemudian berkembang luas dan telah diterapkan untuk mengkarakterisasi teh (Fukusaki dkk., 2006), kopi (Jumhawan dkk., 2013), atau produk herbal (Fujimura dkk., 2011; Wei dkk., 2012).

Perbedaan strain dan kondisi tanam kakao akan mempengaruhi profil senyawa metabolit pada biji kakao. Proses yang terjadi selama fermentasi jaga akan mempengaruhi ragam metabolit yang dihasilkan. Teknik metabolik profiling dapat diterapkan untuk memetakan cita rasa dan mutu biji kakao, yang sedianya hanya dilakukan melalui pengamatan visual dan uji organoleptik. Sebagai contoh Marseglia dkk. (2016) mempublikasikan sebuah hasil penelitiannya tentang penerapan teknik metabolik profiling untuk membedakan biji kakao berdasarkan asalnya.

Makalah ini membahas penerapan teknik metabolik profiling untuk memetakan pengaruh metode pemrosesan pasca panen pada biji kakao. Metode pemrosesan yang dievaluasi meliputi proses fermentasi, baik yang dilakukan secara langsung di kebun ataupun yang dilakukan di laboratorium, dan proses pemanggangan (roasting). Sebagai pembanding, juga dilakukan analisa terhadap sampel biji kakao kontrol, yang tidak difermentasi dan tidak dipanggang.

\section{METODE PENELITIAN Material dan Bahan}

Buah kakao didapatkan dari PT. Perkebunan Nusantara VIII Rajamandala dengan jenis upper amazone dengan hybrid forastero. Buah diperam sampai masak, dibelah, dan diambil bijinya. Sebelum digunakan, pulp biji kakao dibuang secara manual.

Bahan-bahan yang digunakan dalam proses ekstraksi, yaitu campuran metanol, kloroform, dan aquades, dalam proses derivatisasi, yaitu piridin, metoxiamin hidroklorida, dan N-metil-N(trimetilsilil)-trifluoroasetamida (MSTFA), serta sebagai internal standard, yaitu asam nonanoat, berspesifikasi p.a. dan diperoleh dari Sigma-Aldrich (Singapura).

\section{Pemrosesan Biji Kakao}

Enam jenis sampel biji kakao digunakan dalam penelitian ini. Masing-masing sampel telah mengalami 
rangkaian pemrosesan pasca panen yang berbeda, yaitu: biji kakao yang difermentasi di kebun dan disangrai, biji kakao yang difermentasi di laboratorium dan disangrai, biji kakao yang tidak difermentasi dan disangrai, biji kakao yang difermentasi di kebun dan tidak disangrai, biji kakao yang difermentasi di laboratorium dan tidak disangrai, serta biji kakao yang tidak difermentasi dan tidak disangrai.

Fermentasi di kebun dilakukan dalam kotak kayu bertingkat, dan setiap satu atau dua hari sekali dilakukan pemindahan biji dari kotak yang lebih atas ke kotak di bawahnya. Masing-masing kotak dapat berisi sampai $100 \mathrm{~kg}$ biji kakao. Fermentasi laboratorium dilakukan merujuk pada disertasi Stoll (2010). Sebanyak 20 gram biji kakao dikeluarkan dari cangkang buahnya dalam kondisi aseptik, kemudian dimasukkan ke dalam Erlenmeyer steril lalu diinkubasi dalam penangas air. Suhu penangas pada jam ke-24 pertama diset sebesar $30^{\circ} \mathrm{C}$, kemudian setiap 24 jam suhu dinaikkan sebesar $5^{\circ} \mathrm{C}$ hingga jam ke-120.

Biji kakao, baik yang difermentasi ataupun yang tidak difermentasi kemudian dikeringkan di bawah sinar matahari selama 3-4 hari. Penyangraian biji kering dilakukan mengikuti Abeygunasekera dkk. (1989), dalam oven pada suhu $140^{\circ} \mathrm{C}$ selama 30 menit.

\section{Penyiapan Sampel}

Agar dapat dianalisa dengan metode Kromatografi Gas dan Spektroskopi Massa (GC-MS), sampel biji kakao harus melalui beberapa tahap penyiapan sampel yang meliputi ekstraksi metabolit, pemekatan, dan derivatisasi. Metode penyiapan sampel yang diterapkan merupakan adaptasi dari Sakamoto dkk. (2010), yang meliputi ekstraksi dan derivatisasi. Sebagai senyawa standard internal, digunakan asam nonanoat. Penggunaan asam nonanoat dilakukan berdasarkan pertimbangan bahwa dalam daftar senyawa metabolit kakao yang pernah dipublikasikan (Abeygunasekera dkk., 1989; Schnermann dan Schierberle, 1997; Owusu dkk., 2010) tidak terdapat senyawa tersebut, namun terdapat beberapa senyawa metabolit yang mirip dengannya.

Ekstraksi biji kakao dilakukan dengan menggunakan campuran air/metanol/kloroform. Tiga puluh miligram biji kakao digerus dalam nitrogen cair kemudian ditambahkan $1 \mathrm{ml}$ campuran air/metanol/kloroform $(1 / 2,5 / 1)$ dan $60 \mu \mathrm{l}$ standar internal (asam nonanoat), divortex selama 1 menit lalu disentrifugasi pada $4^{\circ} \mathrm{C}, 16.000 \mathrm{~g}$ selama 3 menit. Supernatan diambil sebanyak $900 \mu \mathrm{l}$ kemudian ditambahkan $400 \mu \mathrm{l}$ air mili-Q, divortex selama 1 menit lalu disentrifugasi pada $4^{\circ} \mathrm{C}, 16.000 \mathrm{~g}$ selama 3 menit. Bagian supernatan diambil sebanyak $400 \mu \mathrm{l}$ untuk dievaporasi secara vakum selama setengah jam lalu dikering-bekukan (freeze-drying) selama semalam.

Derivatisasi dilakukan dengan menggunakan methoxiamine dan MSTFA. Sampel hasil freeze- drying diderivatisasi dengan menambahkan $200 \mu \mathrm{l}$ larutan methoxiamine (20 $\mathrm{mg} / \mathrm{ml}$ dalam piridin) kemudian diinkubasi pada $30^{\circ} \mathrm{C}, 1.200 \mathrm{rpm}$ selama 90 menit. Setelah itu dilakukan penambahan $100 \mu \mathrm{l}$ MSTFA, diinkubasi pada $37^{\circ} \mathrm{C}, 1200 \mathrm{rpm}$ selama 30 menit, dan diinkubasi semalaman pada temperatur ruang agar seluruh reaksi berlangsung sempurna. Untuk memfasilitasi proses pelarutan dan penguapan metabolit dalam analisa GC/MS, ke dalam sampel yang telah diderivatisasi ditambahkan heksan.

\section{Analisa Sampel}

Metode analisa diadaptasi dari Abeygunasekera dkk. (1989). Analisis dilakukan menggunakan GC-MS QP 2010 Ultra (Shimadzu) dengan kolom restex 5 ms panjang $30 \mathrm{~m}$, ID 0,25 mikro dan AOC-20i/s (Shimadzu) sebagai autosampler. $1 \mu$ sampel hasil derivatisasi diinjeksikan dengan mode splitless dengan temperatur injeksi $250^{\circ} \mathrm{C}$. Sebagai gas pembawa digunakan Helium dengan kecepatan $0,8 \mathrm{~mL} / \mathrm{menit}$. Temperatur kolom diatur pada $60^{\circ} \mathrm{C}$ selama 1 menit kemudian dinaikkan sampai $300^{\circ} \mathrm{C}$ dengan laju $4^{\circ} \mathrm{C} / \mathrm{min}$ dan ditahan selama 6 menit. Temperatur interface $250^{\circ} \mathrm{C}$, temperatur sumber ion $250^{\circ} \mathrm{C}$, dan menghasilkan ion $70 \mathrm{eV}$. Spektra direkam pada 2000 $\mathrm{u} / \mathrm{s}$ dengan jangkauan massa $10-1000 \mathrm{~m} / \mathrm{z}$. Masingmasing analisa dilakukan dengan 3 replikasi. Sebagai validasi analisa sampel juga dilakukan terhadap bubuk kakao komersil.

Data mentah kromatogram hasil GC-MS dikonversi ke dalam bentuk ANDI (Analytical Data Interchange) menggunakan piranti lunak GC-MS 2010 solution dari Shimadzu. Koreksi dan deteksi data kromatogram dilakukan dengan menggunakan piranti lunak MetAlign (RIKILT, Institute of Food Saferty, Wageningen University and Research Centre). Penjajaran kromatogram dilakukan dengan menggunakan data kromatogram hasil MetAlign berdasarkan puncak standar internal (asam nonanoat) yang memiliki waktu retensi 19,70 menit. Hasil dari penjajaran ini berupa data waktu retensi, noise, dan ukuran puncak. Data hasil rekonsiliasi tersebut dianalisa menggunakan software online analisis multivariat

Metaboanalyst (http://www.metaboanalyst.ca). Analisa dilakukan dengan Principal Component Analysis (PCA). Sebelumnya, dilakukan pemrosesan awal terhadap data yang meliputi penyaringan data (data filtering), transformasi data, dan scaling

\section{HASIL DAN PEMBAHASAN \\ Kestabilan Sampel}

Aplikasi teknik metabolomik metabolik profiling bertujuan mengukur secara semi-kualitatif, berbagai senyawa metabolik yang terkandung dalam sampel. Diharapkan dapat terukur seluruh senyawa metabolik yang terkandung dalam sampel, bahkan tanpa informasi awal senyawa apa sajakah yang ada dalam sampel (untargetted analysis). Dengan demikian hasil pengukuran yang konsisten dari sampel 
ke sampel sangat diharapkan dan kestabilan sampel, terutama apabila jumlah sampel yang akan dianalisa berjumlah banyak, merupakan faktor yang sangat penting. Secara keseluruhan proses penyiapan sampel memakan waktu yang tidak sedikit. Mepertimbangkan waktu analisa sampel dengan GC-MS dan kapasitas GC-MS yang tersedia, perlu dilakukan kajian kestabilan sampel untuk menentukan apakah sampel dapat disiapkan setengah jalan atau disimpan untuk beberapa saat sebelum dianalisa.

Untuk menguji kestabilan sampel, sampel yang sama dianalisa beberapa kali akan tetapi masih pada hari yang sama. Kedua injeksi memberikan jumlah puncak yang sama (Gambar 1a dan b), dengan sedikit perbedaan waktu retensi untuk masing-masing senyawa. Menurut Fowlin (1995), waktu retensi setiap senyawa sangat bervariasi dan bergantung pada titik didih senyawa, kelarutan dalam fasa diam, dan temperatur kolom. Dalam hal ini, karena sampel yang diuji sama dengan sebelumnya maka perbedaan waktu retensi kemungkinan disebabkan oleh temperatur kolom yang sedikit berubah dari kondisi sebelumnya. Dengan demikian sampel cukup stabil dalam jangka waktu 1 hari, akan tetapi kondisi analisa mungkin sedikit berfluktuasi.

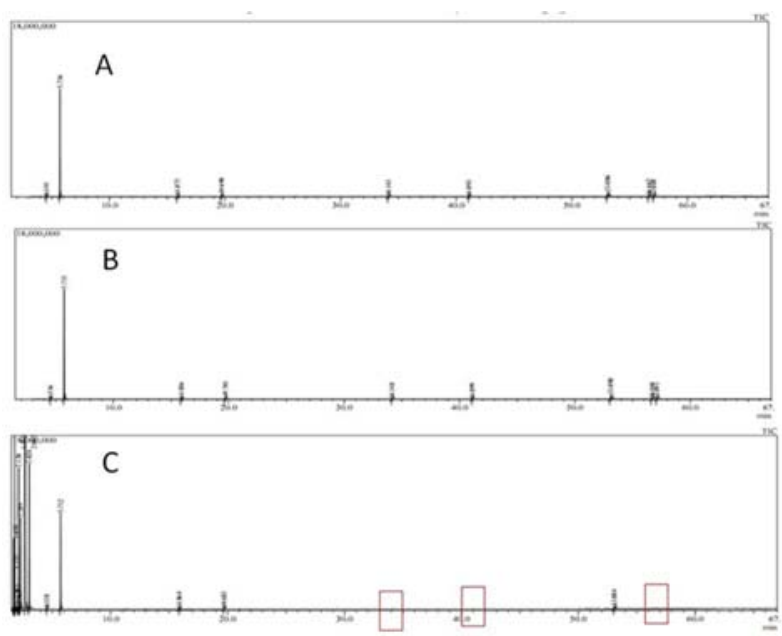

Gambar 1. Kromatogram sampel ekstrak biji kakao dengan perbedaan waktu injeksi dan waktu derivatisasi: sampel yang sama diinjeksikan pada dua waktu yang berbeda (A dan B), ekstrak biji kakao yang sama diderivatisasikan pada hari yang berbeda

(A dan C)

Untuk menguji apakah penyiapan sampel dapat dilakukan dalam beberapa tahapan selama beberapa hari, dilakukan percobaan derivatisasi pada hari yang berbeda terhadap ekstrak biji kakao yang sama. Hal ini secara tidak langsung juga menguji kestabilan ekstrak biji kakao dan kestabilan pelaksanaan proses derivatisasi. Sampel yang disimpan dahulu sebelum diderivatisasi hanya memberikan 5 puncak sementara sampel yang langsung diderivatisasi menunjukkan 9 puncak (Gambar 1a dan c). Analisa lebih lanjut menunjukkan bahwa puncak-puncak yang hilang, sebelumnya terdeteksi dengan luas puncak yang relatif kecil. Hal ini menunjukkan ketidakstabilan ekstrak biji kakao, sehingga senyawa metabolit dengan konsentrasi kecil dapat terdegradasi apabila disimpan dalam waktu yang cukup lama. Dengan demikian proses penyiapan sampel sebaiknya dilakukan sampai tuntas dan langsung dianalisa.

\section{Komposisi Senyawa Metabolit pada Ekstrak Biji Kakao}

Hasil analisa komposisi senyawa metabolit pada berbagai jenis sampel biji kakao dengan berbagai pemrosesan diuraikan pada Tabel 1 .

Tabel 1. Senyawa yang terdeteksi dalam sampel biji kakao dan sampel bubuk coklat komersial

\begin{tabular}{|c|c|c|c|c|c|c|c|}
\hline Fermentasi & $\mathbf{x}$ & keban & lab & $\mathbf{x}$ & kebun & lab & \multirow{2}{*}{$\begin{array}{c}\text { Bubuk } \\
\text { kaka } \\
\text { komer- } \\
\text { sial }\end{array}$} \\
\hline Penyangraian & $\mathbf{x}$ & $\mathbf{x}$ & $\mathbf{x}$ & $\sqrt{ }$ & $\checkmark$ & $\checkmark$ & \\
\hline $\begin{array}{l}\text { silane, chloromethyl- } \\
\text { (CAS)chlorotrimethylsilane }\end{array}$ & v & $\checkmark$ & $\checkmark$ & $\checkmark$ & $\checkmark$ & $\checkmark$ & $\sqrt{ }$ \\
\hline pentanc, 3 smethyl & t & 1 & 西 & d & $\sqrt{2}$ & $\sqrt{ }$ & 1 \\
\hline beksan & $\sqrt{2}$ & $\sqrt{2}$ & $\sqrt{ }$ & $\sqrt{ }$ & $\sqrt{ }$ & $\sqrt{ }$ & $\sqrt{ }$ \\
\hline oomethyl bonafousine & & $\sqrt{1}$ & & & & & \\
\hline nonaborane & & $\frac{d}{d}$ & & & & & \\
\hline $2,5 \bullet$ dimetil 22 & & & $\frac{1}{4}$ & & & & \\
\hline cyclopentane & & & & $\sqrt{2}$ & $\sqrt{1}$ & $\sqrt{ }$ & \\
\hline chloroform & & & & $\sqrt{\mathrm{V}}$ & & & \\
\hline pirolidin & & & $\frac{1}{4}$ & & & & \\
\hline disiloxane, heksametil & $\sqrt{ }$ & $\sqrt{ }$ & $\frac{1}{4}$ & $\sqrt{ }$ & $\sqrt{ }$ & $\sqrt{ }$ & $\sqrt{ }$ \\
\hline acetamide, $2,2,2$ etrifluoro-Nemethyl & $\frac{1}{4}$ & $\frac{1}{4}$ & $\sqrt{1}$ & $\sqrt{2}$ & $\sqrt{2}$ & $\sqrt{ }$ & $\sqrt{ }$ \\
\hline acetic acid & & $\sqrt{1}$ & $\frac{1}{4}$ & $\sqrt{1}$ & & & $\frac{\sqrt{ }}{4}$ \\
\hline piridin & $\sqrt{ }$ & & $\sqrt{ }$ & $\frac{\sqrt{1}}{4}$ & $\sqrt{ }$ & $\sqrt{ }$ & $\frac{1}{4}$ \\
\hline silanamine & $\sqrt{1}$ & & $\sqrt{7}$ & $\sqrt{1}$ & $\sqrt{7}$ & $\sqrt{2}$ & \\
\hline methylamine & & $\sqrt{ }$ & & & & & $\sqrt{ }$ \\
\hline silanamine, Normethoxy & $\sqrt{ }$ & $\frac{\sqrt{1}}{1}$ & $\sqrt{1}$ & $\sqrt{ }$ & $\sqrt{1}$ & $\sqrt{ }$ & $\frac{1}{4}$ \\
\hline $3,6,9$ trioxa $\cdot 2,10$ disilaudckanc & $\frac{4}{4}$ & & & & & & \\
\hline nonanoic acid & $\sqrt{1}$ & $\sqrt{ }$ & $\sqrt{ }$ & $\sqrt{ }$ & $\sqrt{ }$ & $\sqrt{ }$ & $\sqrt{ }$ \\
\hline 1,2,3-propanetricarboxylic acid & & & & & $\frac{1}{4}$ & $\frac{1}{4}$ & \\
\hline $\begin{array}{l}{[1,1 \cdot 1 \cdot \text { 'biphenyl] }-4 \text {-4arboxylic acid, }} \\
\text { trimethylsilyl ester (CAS) }\end{array}$ & v & $\checkmark$ & $\checkmark$ & $\mathrm{v}$ & & & $\sqrt{ }$ \\
\hline D-fructose & & $\mathrm{v}$ & v & & & $\sqrt{ }$ & \\
\hline Doglucitol & & $\sqrt{d}$ & $\sqrt{7}$ & & & & \\
\hline arabilol & & & & & & & $\sqrt{ }$ \\
\hline ribitol & & & $\sqrt{ }$ & & & & \\
\hline 9H-carbuzole,9-phenyl & & & & & & & $\sqrt{ }$ \\
\hline myooinositol & & & & & & $\sqrt{ }$ & \\
\hline inositol & & & $\sqrt{ }$ & & & & $\sqrt{ }$ \\
\hline 2,4-pentadienenitrile & a & $\frac{1}{2}$ & ป & $\sqrt{2}$ & $\sqrt{2}$ & $\sqrt{2}$ & $\frac{1}{4}$ \\
\hline sucrose octams & & & & & & & $\frac{\sqrt{2}}{4}$ \\
\hline silanol & $\sqrt{ }$ & & & & & & \\
\hline propounoic acid & & 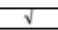 & $\sqrt{2}$ & $\sqrt{2}$ & & & \\
\hline 3,7-dioxe-2,8-disilanonane & & $\frac{1}{4}$ & & & & $\frac{1}{4}$ & $\sqrt{1}$ \\
\hline butanedioic acid & & & & & & & $\frac{1}{4}$ \\
\hline malic acid & & & & & & & $\frac{1}{4}$ \\
\hline lactic acid & & & & & & & $\frac{1}{4}$ \\
\hline silane,[[2-[3,46bis((trimetylsily]) & $\sqrt{ }$ & $\sqrt{ }$ & & $\sqrt{ }$ & $\sqrt{2}$ & & \\
\hline pyridien, 1,4 -dithydro-4 & & & & $\frac{9}{2}$ & & & \\
\hline 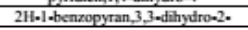 & & & & $\sqrt{v}$ & & & \\
\hline alphwaD-glucopyranoside & $\sqrt{ }$ & & & & $\sqrt{ }$ & & $\sqrt{ }$ \\
\hline
\end{tabular}

Sebagai perbandingan juga ditampilkan hasil analisa komposisi senyawa metabolit pada bubuk kakao komersial. Tidak teridentifikasi senyawasenyawa khas aroma dan rasa seperti senyawasenyawa turunan pirazin dan lakton dalam kedua sampel tersebut. Senyawa-senyawa tersebut cukup dominan pada sampel biji kakao dalam literatur (Abeygunaseekera dkk., 1989; Schnermann dan Schieberle, 1997). Mempertimbangkan bahwa proses penyiapan sampel yang dilaporkan dalam literatur tidak melibatkan proses derivatisasi, juga terdapat kemungkinan bahawa senyawa-senyawa tersebut telah terkonversi dan terdeteksi sebagai senyawa-senyawa turunannya. Kemungkinan lainnya adalah puncakpuncak yang terdeteksi pada hasil analisa GC/MS sampel biji kakao tidak teridentifikasi pada database yang digunakan atau dengan kata lain database yang digunakan kurang tepat untuk mengidentifikasi hasil analisa biji kakao. Sementara itu standard senyawa metabolit biji kakao tidak tersedia. Hal ini merupakan 
permasalahan klasik yang dihadapi dalam penerapan teknik metabolomik untuk sistem biologis (Pohjanen dkk, 2007).

Tabel 1 juga menunjukkan sampel bubuk coklat komersial mengandung lebih banyak senyawa dibandingkan sampel biji kakao yang dianalisa. Hal ini wajar mengingat bubuk coklat diperoleh melalui tahapan-tahapan proses curing, yaitu pembentukan aroma dan rasa, yang lebih lengkap dibandingkan dengan sampel biji kakao yang dianalisa.

\section{Pemetaan Pengaruh Berbagai Pemrosesan pada Biji Kakao}

Studi metabolomik pada penelitian ini bertujuan untuk mengetahui apakah terdapat perbedaan kandungan senyawa metabolit pada biji kakao dengan enam perlakuan proses yang berbeda, difermentasi (di kebun atau di laboratorium) dan disangrai. Tampilan keenam jenis sampel biji kakao tersebut ditunjukkan pada Gambar 2.

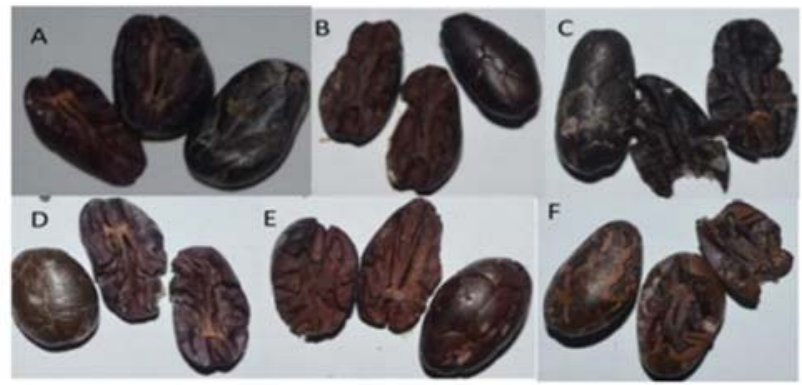

Gambar 2. Tampilan biji kakao kering, A : Biji tidak difermentasi, tidak disangrai, B : Biji hasil fermentasi kebun, tidak disangrai, $\mathrm{C}: \mathrm{Biji}$ hasil fermentasi laboratorium, tidak disangrai, D : Biji tidak difermentasi, disangrai, E : Biji hasil fermentasi kebun, disangrai, $\mathrm{F}$ : Biji hasil fermentasi laboratorium, disangrai.

Secara fisik terlihat bahwa biji kakao yang tidak difermentasi masih berwarna keunguan, sedangkan biji kakao terfermentasi, baik hasil fermentasi di kebun maupun fermentasi di laboratorium bagian dalamnya telah berubah warna menjadi coklat kehitaman. Perbedaan warna ini terjadi karena peran dari enzim oksidatif, polifenol oksidase, yang muncul terakhir pada fase aerobik fermentasi dan proses berlanjut ke pengeringan kakao (Thompson dkk., 2001). Katekin dan leukosianidin adalah kelas utama polifenol yang dioksidasi dalam biji kakao, membentuk senyawa-senyawa quinon yang akan mengalami polimerisasi dengan polifenol lainnya atau membentuk kompleks dengan asam amino dan protein menghasilkan senyawa warna yang karakteristik dan material dengan berat molekul besar yang tidak larut. Pembentukan senyawa kompleks ini mengurangi rasa asam dan pahit yang disebabkan oleh polifenol alami pada kakao tanpa fermentasi (Thompson dkk., 2001). Perbedaan komposisi senyawa metabolit ini diharapkan dapat terlihat dari pemetaan metabolit biji kakao.
Keseluruhan puncak yang dihasilkan dari hasi analisa GC/MS dimasukkan ke software pengolahan data metaboanalyst (http://www.metaboanalyst.ca/). Dengan demikian, ketidaksesuaian penamaan atau identifikasi puncak senyawa yang terdeteksi oleh database yang digunakan tidak akan berpengaruh terhadap akurasi pemetaan metabolik yang dilakukan. Hal ini merupakan salah satu keunggulan yang ditawarkan oleh metode metabolik profiling: walaupun senyawa metabolit yang terdeteksi belum dapat dikenali atau diidentifikasi dengan pasti, kehadirannya dapat digunakan untuk membedakan berbagai jenis sampel.

Hasil analisa menunjukkan bahwa 88,6\% variasi komposisi metabolit antar sampel biji kakao dengan berbagai perlakuan proses dapat dijelaskan dengan baik menggunakan 2 buah Principal Component (PC). PC 1 dapat menjelaskan 76,8\% dari variasi komposisi metabolit antar sampel, PC 2 dapat menjelaskan sebesar $11,8 \%$ dari variasi. PC 3 menjelaskan 3,5\% dari variasi, sedangkan variasi yang dapat dijelaskan oleh PC-PC selanjutnya semakin kecil, dan menjadi tidak signifikan. Dengan demikian data yang ada dapat dipetakan dengan cukup baik dalam 2 dimensi, menggunakan PC 1 dan PC 2 saja (Gambar 3).

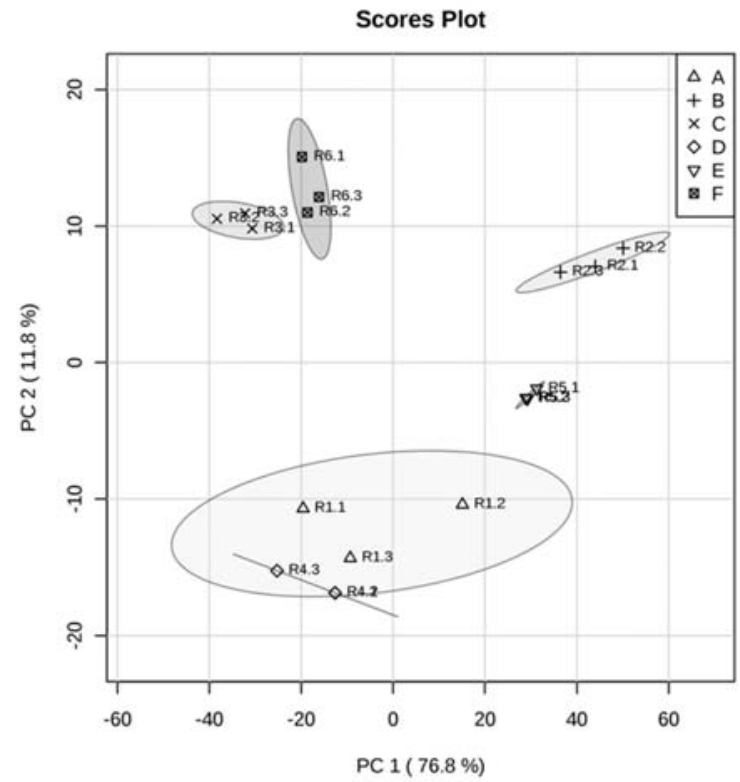

Gambar 3. Score plot PC 1 dan PC 2 dari komposisi metabolit biji kakao dengan berbagai perlakuan proses

(A: Biji tidak difermentasi tidak disangrai, B: Biji

hasil fermentasi kebun tidak disangrai, $\mathrm{C}$ : Biji hasil fermentasi laboratorium tidak disangrai, D: Biji tidak difermentasi disangrai, E: Biji hasil fermentasi kebun

disangrai, F: Biji hasil fermentasi laboratorium disangrai)

Hasil yang diperoleh menunjukkan bahwa terdapat perbedaan yang berarti antara keenam kelompok sampel biji kakao yang diujikan. Kelompok sampel A, yaitu biji kakao yang sama sekali tidak difermentasi ataupun disangrai menunjukkan variasi 
yang paling lebar antar sampelnya. Sementara kelompok sampel E, yaitu biji kakao yang difermentasi kebun dan disangrai menunjukkan variasi sampel yang paling sempit. Secara umum terlihat bahwa pemrosesan biji kakao, baik itu fermentasi kebun ataupun fermentasi laboratorium, maupun penyangraian mengarahkan biji kakao sehingga diperoleh sebaran variasi metabolit yang lebih sempit.

Hal menarik lainnya adalah proses fermentasi menyebabkan terbentuknya metabolit yang spesifik sehingga terlihat perbedaan yang nyata antara kelompok sampel biji kakao yang difermentasi (B, C, E, dan F) dan kelompok biji kakao yang tidak difermentasi (A dan D). Penyangraian biji kakao, tanpa didahului proses fermentasi hanya mengurangi sebaran variasi komposisi senyawa metabolit biji kakao, tanpa membentuk senyawa-senyawa baru (A dan D). Sebaliknya pada proses proses penyangraian biji kakao yang dilakukan setelah proses fermentaasi, senyawa-senyawa metabolit spesifik yang terbentuk pada proses fermentasi akan terkonversi lanjut, sehingga terlihat jelas perbedaan antara kelompok biji kakao yang difermentasi saja dengan kelompok biji kakao yang difermentasi dan disangrai (perubahan koordinat kelompok biji kakao B ke E, dan perubahan koordinat kelompok biji kakao C ke F).

Analisa lanjutan dapat dilakukan untuk menentukan senyawa apakah yang memiliki peranan penting dalam membedakan keenam kelompok perlakuan biji kakao tersebut, misalnya dengan menerapkan metode analisa tersupervisi Partial Least Square Discriminant Analysis (PLS-DA). Metode ini dapat memberikan hasil analisa yang lebih rinci mengenai senyawa metabolit yang mengakibatkan perbedaan signifikan antara dua atau lebih kelompok sampel (Worley dan Powers, 2013), yang ditunjukkan dengan hasil analisa Variabel Important in Projection (VIP) scorenya. Namun demikian, menggunakan data-data yang tersedia, penerapan metode ini baru dapat menghasilkan daftar senyawa dengan waktu retensi dan berat molekul tertentu. Dengan menggunakan database yang tepat, senyawa-senyawa ini dapat diidentifikasi.

\section{KESIMPULAN}

Pendekatan metabolomik dapat diterapkan untuk memetakan pengaruh proses yang dilakukan terhadap komposisi senyawa metabolit biji kakao atau kualitas biji kakao secara umum. Profil metabolit yang diperoleh menunjukkan bahwa terdapat perbedaan yang signifikan antara berbagai perlakuan proses terhadap komposisi senyawa metabolit biji kakao. Biji kakao yang tidak difermentasi dan tidak disangrai memiliki sebaran variasi komposisi senyawa metabolit yang sangat lebar. Fermentasi mengakibatkan terbentuknya komposisi senyawa metabolit yang sangat berbeda sehingga dapat memberikan pengaruh yang signifikan terhadap kualitas biji kakao. Analisa lanjut perlu dilakukan, menggunakan database yang tepat, untuk memperoleh identitas senyawa-senyawa yang memiliki peran besar dalam diskriminiasi keenam kelompok perlakuan biji kakao tersebut.

\section{UCAPAN TERIMA KASIH}

Penelitian ini didanai oleh Riset Peningkatan Kapasitas ITB dengan judul 'Pengembangan Metode Fermentasi Dan Sistem Identifikasi Fingerprinting Metabolik Untuk Peningkatan Mutu Biji Kakao Olahan Indonesia'.

\section{DAFTAR PUSTAKA}

Abeygunasekera, D.D., Mubarak, A.M., and Jansz, E. R., (1989), The Volatiles of Cocoa by GC/MS Analysis and Sensory Evaluation with Special Emphasis on the Effect of Fermentation Time and Maturation, J. Natn. Sci. Coun. Sri Lanka, 17(2), pp. 229-235.

Fiehn, O., Kopka, J., Trethewey, R.N., and Willmitzer, L., (2000), Identification of Uncommon Plant Metabolites Based on Calculation of Elemental Compositions Using Gas Chromatography and Quadrupole Mass Spectrometry, Anal. Chem, 72, pp. 3873-3880.

Fowlin, I.A., (1995), Gas Chromatography, 2nd Edition, John Wiley \& Sons Ltd, Manchester, UK.

Fujimura, Y., Kurihara, K., Ida, M., Kosaka, R., Miura, D., Wariishi, H., Maeda-Yamamoto, M., Nesumi, A., Saito, T., Kanda, T., Yamada, K., and Tachibana, H., (2011), Metabolomics-driven Nutraceutical Evaluation of Diverse Green Tea Cultivars, PloS One, 6(8), e23426.

Fukusaki, E., Jumtee, K., Bamba,T., Yamaji, T., and Kobayashi, A., (2006), Metabolic Fingerprinting and Profiling of Arabidopsis thaliana Leaf and Its Cultured Cells T87 by GC/MS, Z. Naturforsch, 61c, pp. 267-272.

Halket, J.M., Waterman, D., Przyborowska, A.M., Patek, R.K., Fraser, P.D., and Bramley, P.M., (2005), Chemical Derivatization and Mass Spectral Libraries in Metabolic Profiling by GC/MS and LC/MS/MS, Journal of Experimental Botany, 56(410), pp. 219243.

Jumhawan, U., Putri, S.P., Yusianto, Marwani, E., Bamba, T., and Fukusaki, E., (2013), Selection of Discriminant Markers for Authentication of Asian Palm Civet Coffee (Kopi Luwak): A Metabolomics Approach, J.Agric.Food Chem, 61, pp.7994-8001

Kresnowati, M.T.A.P. and Febriami, H., (2016), Mapping the Effects of Starter Culture Addition on Cocoa Bean Fermentation, ASEAN Engineering Journal Part B, 5(1), pp. 25-37

Kopka, J., (2006), Current Chalenges and Developments in GC-MS based metabolite Profiling 
Technology, Journal of Biotechnology, 124, pp. 312322

Marseglia, A., Acquotti, D., Consonni, R., Cagliani, L.R., Palla, G., and Caligiani, A., (2016), HR MAS 1 H NMR and Chemometrics as Useful Tool to Assess the Geographical Origin of Cocoa Beans Comparison with HR 1H NMR, Food Research International, 85, pp. 273-281.

Owusu, M., Petersen, M.A., and Heimdal, H., (2010), Asessment of Aroma of Chocolate Produced from Two Ghanaian Cocoa Fermentation Types, in Blank I, Wüst M, Yeretzian C, (editors), Expression of Multidisciplinary Flavour Science: Proceedings of the 12th Weurman Symposium, Switzerland, 2008. Zurich University of Applied Sciences. 2010. pp. 363-366.

Pohjanen, E., Thysell, E., Lindberg, J., SchuppeKoistinen, I., Moritz, T., Jonsson, P., and Antti, H., (2007), Statistical Multivariate Metabolite Profiling for Aiding Biomarker Pattern Detection and Mechanistic Interpretations in GC/MS Based Metabolomics, Metabolomics, 2 (4), pp.257-268.

Sakamoto, Y., Nakagawa, K., Kawana, S., Lingga, N., Chin, H.L., and Miyagawa, H., (2010), Profiling of Japanese Green Tea Metabolites by GCMS, GCMS Technical Report No.1.Shimadzu Corporation

Schnermann, P. and Schieberle, P., (1997), Evaluation of Key Odorants in Milk Chocolate and Cocoa Mass by Aroma Extract Dilution Analyses, J.Agric. Food Chem, 45, pp. 867-872

Schwan, R.F., (1998), Cocoa Fermentation Conducted with a Defined Microbial Cocktail Inoculum. Appl Environ Microbiol, 64(4), pp. 1477-1483

Schwan, R.F. and Wheals, A.E., (2004), The Microbiology of Cocoa Fermentation and Its Role in
Chocolate Quality, Food Science and Nutrition, 44, pp. 205-221

Skogerson, K., Runnebaum, R., Wohlgemuth, G., de Ropp, J., Heymann, H., and Fiehn, O., (2009), Comparison of Gas Chromatography-Coupled Timeof-Flight Mass Spectrometry and ${ }^{1} \mathrm{H}$ Nuclear Magnetic Resonance Spectroscopy Metabolite Identification in White Wines from a Sensory Study Investigating Wine Body, J. Agric. Food Chem., 57, pp. $6899-6907$

Stoll, L., (2010), Biochemische Indikatoren fur Keimung unf Fermentation in Samen von Kakao (Theobroma cacao L.), Universitat Hamburg.

Thompson, S.S., Miller, K.B., and Lopez, A.S., (2001), Food Microbiology: Fundamentals and Frontiers, Second Edition. ASM Press. Washington, D. C.

Wei, F., Furihata, K., Koda, M., Hu, F., Miyakawa, T., and Tanokura, M., (2012), Roasting Process of Coffee Beans as Studied by Nuclear Magnetic Resonance: Time Course of Changes in Composition, J.Agric.Food Chem., 60, pp. 1005-1012

Wolfender, J., Guillaume, M., Thomas, A., and Bertrand, S., (2015), Current Approaches and Challenges for the Metabolite Profiling of Complex Natural Extracts, Journal of Chromatography A, 1382, pp. 136-164.

Worley, B. and Powers, R., (2013) Multivariate Analysis in Metabololomics. Curr. Metabolomics, 1(1), pp. 92-107. 